\title{
MONITORING OSMOTHERAPY IN TRAUMATIC BRAIN INJURY PATIENTS: CORRELATION BETWEEN ULTRASOUND ASSESSMENT OF OPTIC NERVE SHEATH DIAMETER AND COMPUTED TOMOGRAPHY SCAN
}

\author{
${ }^{1}$ Salwa Omar Elkhattab Amin, ${ }^{1}$ Galal Adel Alkady, ${ }^{2}$ Hossam Mohammed \\ Mohammed Elmorshedy, ${ }^{1}$ Waleed Abdallah Ibrahim
}

\author{
${ }^{1}$ Department of Anesthesiology, \\ Intensive Care and Pain \\ Management, Faculty of \\ Medicine, Ain Shams University \\ ${ }^{2}$ Department of Intensive Care, \\ Belbis General Hospital, Egypt. \\ Corresponding author \\ Hossam Mohammed M. \\ Elmorshedy Elazeem \\ Mobile: (+2) 01011348911 \\ E.mail: \\ Email: \\ dr.hossam7789@gmail.com \\ Received: 4/8/2021 \\ Accepted: 31/8/2021
}

Online ISSN: 2735-3540

\begin{abstract}
:
Background: Traumatic brain injury has been one of the leading causes of morbidity, disability and mortality across all ages, globally, more than 50 million individuals suffer from TBIs each year. In Egypt it poses a major public health problem, representing $17.2 \%$ of trauma patients. Intracranial pressure is a major predictor of neurological deterioration in patients with TBI and post-traumatic intracranial hypertension is being associated with poor neurological outcome.
\end{abstract}

Aim of the Work: To compare ultrasound assessment of optic nerve sheath diameter as a monitoring tool of adequacy of brain dehydration by osmotherapy in traumatic brain injury in comparison to the current standard of using brain $C T$.

Patients and Methods: This study is a Prospective Observational study was conducted on 30 participants. All patients were polytrauma after road traffic accident with traumatic brain injury and were recruited from intensive care unit in Ain Shams University Hospitals during the period of February 2021 to May 2021.

Results: There was highly statistically significant decrease in right ONSD and left ONSD before and after mannitol from day 1 to day 3. There was highly statistically significant decrease in brain edema from day 1 to day 3 after osmotherapy. There was highly statistically significant relation found between CT brain edema and right ONSD and left ONSD before and after mannitol administration in third day, as CT brain already positive in first and second day.

Conclusion: We concluded that ONSD could be used as a tool to evaluate the efficacy and successful treatment by dehydrating measures in cases of increased ICP and can be utilized as a tool for decision making and point-of-care utility.

Keywords: Intracranial pressure, intracerebral haemorrhage, subarachnoid haemorrhage

\section{INTRODUCTION:}

Elevated intracranial pressure (ICP) and cerebral edema are common neurologic complications of various cerebral disorders, such as traumatic brain injury (TBI), intracerebral haemorrhage (ICH) \& subarachnoid haemorrhage (SAH) ${ }^{(1)}$.
Early detection, evaluation and treatment of elevated ICP improve outcome of TBI. Invasive ICP monitoring is the gold standard method for ICP monitoring, but invasive techniques are associated with risk of complications such as hemorrhage and 
infection, also, it is not available in all places and requires high expertise ${ }^{(2)}$.

Some non-invasive methods for measuring ICP can be used as alternatives to invasive techniques, including transcranial Doppler, optic nerve sheath diameter (ONSD), computed tomography (CT), magnetic resonance imaging (MRI), and fundoscopy ${ }^{(2)}$.

These non-invasive techniques do not carry the risk of complications as with invasive methods. Recently, adult studies have reported that measuring ONSD with non-invasive imaging technologies such as CT, MRI and ultrasound can be used as an alternative method to evaluate increased $\mathrm{ICP}^{(3)}$.

However, CT and MRI for ONSD measurements are time consuming, costly and usually require patient transportation. Thus, ultrasound assessments of ONSD could be a better option because reliable, accessible, easy to learn, low cost and rapid bedside operation without the need for radiation exposure, especially for cases that are unstable and require real-time monitoring of ICP in an intensive care unit $^{(4)}$.

The optic nerve sheath is continuous with the meninges of the central nervous system and is encased with the subarachnoid membrane. Cerebrospinal fluid (CSF), located in the subarachnoid space, accumulates in the optic nerve sheath thereby widening its diameter in the setting of increased ICP and limited intracranial compliance $^{(5)}$.

Osmotherapy is one treatment intervention in the care of patients with severe head injury resulting in cerebral edema and intracranial hypertension. The effect of hyperosmolar solutions on brain tissue was first studied nearly 90 years ago. Since that time, mannitol has become the most widely used hyperosmolar solution to treat elevated intracranial pressure ${ }^{(6)}$.

\section{AIM OF THE WORK:}

To compare ultrasound assessment of optic nerve sheath diameter as a monitoring tool of adequacy of brain dehydration by osmotherapy in traumatic brain injury in comparison to the current standard of using brain CT.

\section{PATIENTS AND METHODS:}

This study is a Prospective Observational study was conducted on 30 participants.

All patients were recruited from intensive care unit in Ain Shams University Hospitals during the period of February 2021 to May 2021.

Informed oral consent was obtained from legal guardians for every patient after explaining the content and implication of the study, which was reviewed and approved by the ethical committee of the Faculty of Medicine, Ain Shams University.

Inclusion criteria: We included in this study 30 Polytrauma patients after road traffic accident with traumatic brain injury, more than 18 years old from both genders and CT brain in trauma survey show signs of increasing ICP and need to receive osmotherapy with mannitol $20 \%$.

Exclusion Criteria: We exclude all patients with past history of glaucoma or cataract of any eye or previous ocular surgery, patients with trauma of eye globe or edematous eye lids, patients with conditions associated with increase optic nerve sheath diameter like optic nerve trauma, anterior orbital or cavernous sinus mass and arachnoid cyst of the optic nerve, finally patients who planned for decompressive cranial surgery.

All patients were subjected to the following: Complete history taking and 
clinical examination including vital data and Glasgow Coma Scale (GCS).

\section{Laboratory investigations:}

Routine daily lab investigations including: Complete blood count (CBC), Arterial blood gases (ABG), Serum $\mathrm{Na}+$ and $\mathrm{K}+$, Blood urea and serum creatinine, Random blood glucose (RBS). Electrolyte checking was performed due to the adverse effects of mannitol including hypovolemia, electrolyte disorders, renal failure and hyperosmolarity in all patients.

Radiological parameters: including the following:

Ocular ultrasound: To assess optic nerve sheath diameter, it was done 30 minutes before starting dose of mannitol and 60 minutes after receiving the treatment with mannitol 20\%, for 3 times per day and for 3

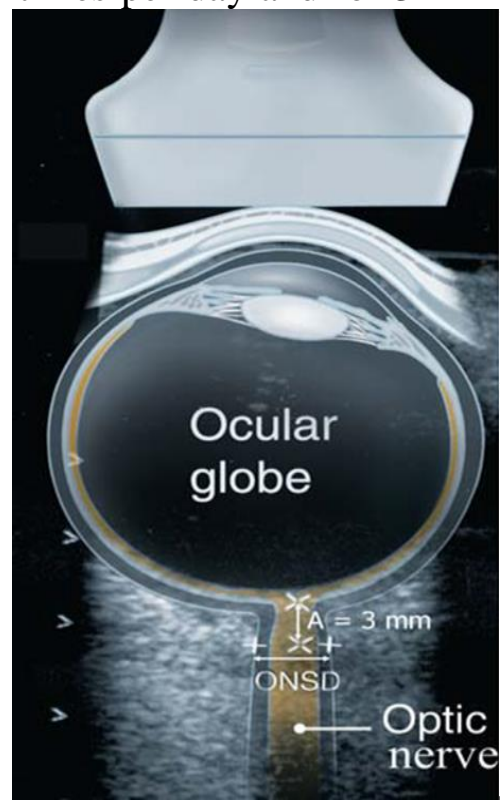

consecutive days for each eye. Ultrasonographic measurement of ONSD was done using a 7.5-10 MHZ linear ultrasound probe.

All patients were examined in the supine position. Conductive ultrasound gel was placed over a closed upper eyelid without any pressure.

The probe was placed on the superior and lateral aspect of the orbit as is the recommended technique.

Optic nerve was visualized as a linear hypoechoic structure with defined margins posterior to the globe. The transverse ONSD was measured $3 \mathrm{~mm}$ behind the retina as shown in Image A and B and noted. Based on prior literature, binocular ONSD $5.0 \mathrm{~mm}$ was considered raised in this study.

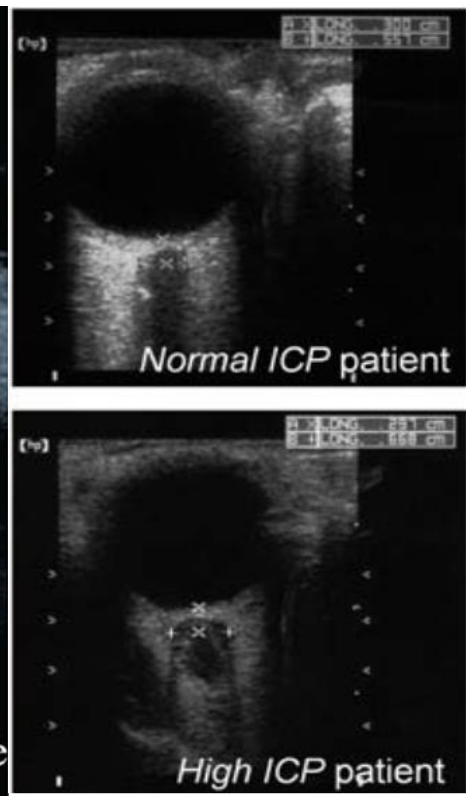

Figure (1): A) show how to measure ONSD, B) show difference between normal and increasing ICP.

\section{CT brain:}

To detect brain injury and increased ICP at first, then repeat after 24 hours for follow up and third one after receiving all needed doses of osmotherapy. Edema is visible as areas of low density and loss of gray/white matter differentiation, on an unenhanced image. There can also be the obliteration of the cisterns and sulcal spaces. If flattened gyri or narrowed sulci, or compression of the ventricles, is seen, this suggests increased ICP. We depend on radiology specialists opinion about the existence of brain edema or not and expresses that by positive or negative values.

\section{Therapeutic parameters:}

All patients receive osmotherapy by Mannitol 20\% in the recommended dose for 
adults: 0.5 to $2 \mathrm{~g} / \mathrm{kg}$ IV over at least $30 \mathrm{~min}$ every $8 \mathrm{hrs}$.

\section{Statistical Analysis:}

Statistical analysis of collected data was done using SPSS program (Statistical Package of Social Science) version 23.

1- Descriptive statistics: Mean and standard deviation (SD) were collected to measure quantitative variables. Frequency of occurrence was calculated to measure qualitative data.

2- Analytic statistics: Independentsamples t-test of significance was used when comparing between two means. Chi-square (X2) test of significance was used in order to compare proportions between two qualitative parameters. Pearson's correlation coefficient (r) test was used for correlating data. Probability (P-value): P-value $<0.05$ was considered significant. P-value $<0.01$ was considered as highly significant. P-value $>0.05$ was considered insignificant.

ROC-curve: Receiver Operating Characteristic curve analysis. Sensitivity: Probability that the test results will be positive when the disease is present (true positive rate, expressed as a percentage). Specificity: Probability that the test results will be negative when the disease is present (true negative rate, expressed as a percentage). PPV: Positive Predictive value (probability that the disease is present when the test is positive). NPV: Negative Predictive value (probability that the disease is present when the test is negative). Accuracy: The ratio of the true positive and true negative on all patients.

\section{RESULTS:}

Table (1): Demographic characteristics of 30 patients with increased ICP:

\begin{tabular}{|l|l|c|}
\hline \multicolumn{2}{|l|}{} & No. $=30$ \\
\hline Age & Mean \pm SD & $34.70 \pm 10.07$ \\
\cline { 2 - 3 } & Range & $18-52$ years \\
\hline \multirow{2}{*}{ Sex } & Female & $5(16.7 \%)$ \\
\cline { 2 - 3 } & Male & $25(83.3 \%)$ \\
\hline \multirow{2}{*}{ Weight } & Mean \pm SD & $85.63 \pm 16.90$ \\
\cline { 2 - 3 } & Range & $60-121 \mathrm{~kg}$ \\
\hline Initial GCS / 15 & Mean \pm SD & $9.23 \pm 2.88$ \\
& Range & $4-12$ \\
\hline Initial CT brain findings & Brain edema & $30(100.0 \%)$ \\
& Brain contusion & $9(30.0 \%)$ \\
& SDH & $7(23.3 \%)$ \\
& SAH & $6(20.0 \%)$ \\
& Pneumocephaly & $3(10.0 \%)$ \\
& EDH & $2(6.7 \%)$ \\
& ICH & $2(6.7 \%)$ \\
& Skull fracture & $1(3.3 \%)$ \\
\hline
\end{tabular}


Table (2): Follow up of vital data among studied patients with increased ICP along 3 successive days

\begin{tabular}{|c|c|c|c|c|c|c|c|}
\hline \multirow{2}{*}{\multicolumn{2}{|c|}{ Vital data }} & Day 1 & Day 2 & Day 3 & \multirow{3}{*}{$\begin{array}{c}\begin{array}{c}\text { Test } \\
\text { value }\end{array} \\
1.155\end{array}$} & \multirow[t]{2}{*}{ P-value } & \multirow[t]{2}{*}{ Sig. } \\
\hline & & No. $=30$ & No. $=30$ & No. $=30$ & & & \\
\hline \multirow[t]{2}{*}{ SBP } & Mean \pm SD & $120.67 \pm 8.12$ & $121.33 \pm 8.60$ & $123.17 \pm 7.90$ & & \multirow[t]{2}{*}{0.319} & \multirow[t]{2}{*}{ NS } \\
\hline & Range & $105-135 \mathrm{mmHg}$ & $115-145 \mathrm{mmHg}$ & $105-137.5 \mathrm{mmHg}$ & & & \\
\hline \multirow[t]{2}{*}{ DBP } & Mean \pm SD & $74.67 \pm 6.29$ & $74.00 \pm 4.62$ & $75.50 \pm 5.27$ & \multirow[t]{2}{*}{0.674} & \multirow[t]{2}{*}{0.508} & \multirow[t]{2}{*}{ NS } \\
\hline & Range & $65-85 \mathrm{mmHg}$ & $65-85 \mathrm{mmHg}$ & $65-85 \mathrm{mmHg}$ & & & \\
\hline \multirow[t]{2}{*}{$\mathrm{HR}$} & Mean \pm SD & $96.30 \pm 15.91$ & $94.10 \pm 12.75$ & $99.13 \pm 16.29$ & \multirow[t]{2}{*}{1.482} & \multirow[t]{2}{*}{0.238} & \multirow[t]{2}{*}{ NS } \\
\hline & Range & $72-125.5$ & $77-118$ & $69-120.5$ & & & \\
\hline \multirow[t]{2}{*}{ Temperature } & Mean \pm SD & $37.34 \pm 0.23$ & $37.33 \pm 0.31$ & $37.40 \pm 0.35$ & \multirow[t]{2}{*}{0.711} & \multirow[t]{2}{*}{0.492} & \multirow[t]{2}{*}{$\mathrm{NS}$} \\
\hline & Range & $37-37.9 \mathrm{C}$ & $36.95-38.2 \mathrm{C}$ & $37-38.1 \mathrm{C}$ & & & \\
\hline \multirow[t]{2}{*}{ CVP } & Mean \pm SD & $6.13 \pm 1.76$ & $7.17 \pm 1.09$ & $7.47 \pm 1.32$ & \multirow[t]{2}{*}{7.298} & \multirow[t]{2}{*}{0.002} & \multirow[t]{2}{*}{$\mathrm{HS}$} \\
\hline & Range & $3.5-9 \mathrm{mmHg}$ & $5-9 \mathrm{mmHg}$ & $5.5-11 \mathrm{mmHg}$ & & & \\
\hline GCS\15 & $\begin{array}{l}\text { Mean } \pm \text { SD } \\
\text { Range }\end{array}$ & $\begin{array}{c}9.23 \pm 2.88 \\
4-12\end{array}$ & $\begin{array}{c}10.10 \pm 3.36 \\
5-14\end{array}$ & $\begin{array}{c}11.47 \pm 4.00 \\
5-15\end{array}$ & 19.649 & 0.000 & HS \\
\hline
\end{tabular}

P-value >0.05: Non significant (NS); P-value <0.05: Significant (S); P-value< 0.01: highly significant $(\mathrm{HS}) \bullet:$ Repeated measure ANOVA test

Table (3): Follow up of laboratory parameters among studied patients with increased ICP along 3 successive days

\begin{tabular}{|c|c|c|c|c|c|c|c|}
\hline \multirow{2}{*}{\multicolumn{2}{|c|}{$\begin{array}{l}\text { Laboratory } \\
\text { parameters }\end{array}$}} & \multirow{2}{*}{$\begin{array}{c}\text { Day } 1 \\
\text { No. }=30\end{array}$} & \multirow{2}{*}{$\begin{array}{c}\text { Day } 2 \\
\text { No. }=30\end{array}$} & \multirow{2}{*}{$\begin{array}{c}\text { Day } 3 \\
\text { No. }=30\end{array}$} & \multirow{2}{*}{$\begin{array}{c}\text { Test } \\
\text { value }\end{array}$} & \multirow[t]{2}{*}{ P-value } & \multirow[t]{2}{*}{ Sig. } \\
\hline & & & & & & & \\
\hline $\mathrm{Ph}$ & Mean \pm SD & $7.32 \pm 0.07$ & $7.39 \pm 0.05$ & $7.40 \pm 0.04$ & $20.828 \bullet$ & 0.000 & HS \\
\hline & Range & $7.22-7.44$ & $7.27-7.48$ & $7.31-7.47$ & & & \\
\hline Pco2 & Mean \pm SD & $43.00 \pm 10.24$ & $40.72 \pm 6.18$ & $42.08 \pm 5.56$ & $0.749 \bullet$ & 0.445 & NS \\
\hline & Range & $23-67 \mathrm{mmHg}$ & $32.2-57 \mathrm{mmHg}$ & $33-58 \mathrm{mmHg}$ & & & \\
\hline Hco3 & Mean \pm SD & $21.49 \pm 3.92$ & $23.93 \pm 1.75$ & $25.22 \pm 2.10$ & $14.712 \bullet$ & 0.000 & HS \\
\hline & Range & $\begin{array}{c}12.2-27.4 \\
\mathrm{mEq} / \mathrm{L}\end{array}$ & $\begin{array}{c}20.3-26.7 \\
\mathrm{mEq} / \mathrm{L}\end{array}$ & $\begin{array}{c}22.2-29.1 \\
\mathrm{mEq} / \mathrm{L}\end{array}$ & & & \\
\hline Po2 & Median (IQR) & $60(47-144)$ & $63.9(35.4-91)$ & $89(53-179)$ & $3.267 \ddagger$ & 0.195 & NS \\
\hline & Range & $16-201 \mathrm{mmHg}$ & $20-183 \mathrm{mmHg}$ & $16.1-215 \mathrm{mmHg}$ & & & \\
\hline So 2 & Mean \pm SD & $79.87 \pm 25.86$ & $80.00 \pm 23.66$ & $91.17 \pm 17.83$ & $3.489^{\bullet}$ & 0.048 & $\mathrm{~S}$ \\
\hline & Range & $14-100$ & $24-100$ & $28-100$ & & & \\
\hline $\mathrm{HB}$ & Mean \pm SD & $12.73 \pm 1.49$ & $11.47 \pm 1.63$ & $9.64 \pm 2.81$ & $22.804 \bullet$ & 0.000 & HS \\
\hline & Range & $9.5-14.8 \mathrm{gm} / \mathrm{dL}$ & $9.70-15.1 \mathrm{gm} / \mathrm{dL}$ & $10.9-13.8 \mathrm{gm} / \mathrm{dL}$ & & & \\
\hline TLC & Median (IQR) & $18.8\left(12.6 \_24.7\right)$ & $12.7(11-17.9)$ & $11.7(10.1-15.5)$ & $24.267 \ddagger$ & 0.000 & HS \\
\hline & Range & $7-27.6 \mathrm{~mm} 3$ & $6.1-30 \mathrm{~mm} 3$ & $6-30.5 \mathrm{~mm} 3$ & & & \\
\hline PLT & Mean \pm SD & $239.69 \pm 86.29$ & $217.55 \pm 72.71$ & $175.13 \pm 53.16$ & $6.547 \bullet$ & 0.005 & HS \\
\hline & Range & $223-345 \mathrm{~mm} 3$ & $282-310 \mathrm{~mm} 3$ & $95-315 \mathrm{~mm} 3$ & & & \\
\hline HTC & Mean \pm SD & $34.40 \pm 4.85$ & $31.41 \pm 5.52$ & $30.00 \pm 7.02$ & $7.503 \bullet$ & 0.005 & HS \\
\hline & Range & $26.8-40.6$ & $25.1-40.8$ & $19.1-39.6$ & & & \\
\hline $\mathrm{Na}$ & Mean \pm SD & $140.73 \pm 5.78$ & $140.67 \pm 7.03$ & $140.93 \pm 6.70$ & 0.054 & 0.921 & NS \\
\hline & Range & $134-157 \mathrm{mEq} / \mathrm{L}$ & $130-160 \mathrm{mEq} / \mathrm{L}$ & $132-163 \mathrm{mEq} / \mathrm{L}$ & & & \\
\hline $\mathrm{K}$ & Mean \pm SD & $3.53 \pm 0.69$ & $3.72 \pm 0.46$ & $4.09 \pm 0.58$ & 8.520 & 0.001 & HS \\
\hline & Range & $2.6-5.4 \mathrm{mEq} / \mathrm{L}$ & $3.1-5 \mathrm{mEq} / \mathrm{L}$ & $3.1-5.5 \mathrm{mEq} / \mathrm{L}$ & & & \\
\hline S.Create & Mean \pm SD & $1.12 \pm 0.54$ & $1.01 \pm 0.37$ & $0.92 \pm 0.44$ & 5.476 & 0.012 & $\mathrm{~S}$ \\
\hline & Range & $0.6-2.6 \mathrm{gm} / \mathrm{dL}$ & $0.5-1.8 \mathrm{gm} / \mathrm{dL}$ & $0.5-2.1 \mathrm{gm} / \mathrm{dL}$ & & & \\
\hline UREA & Mean \pm SD & $37.67 \pm 12.34$ & $42.00 \pm 16.54$ & $42.00 \pm 16.79$ & 0.864 & 0.412 & NS \\
\hline & Range & $18-66 \mathrm{gm} / \mathrm{dL}$ & $22-93 \mathrm{gm} / \mathrm{dL}$ & $26-97 \mathrm{gm} / \mathrm{dL}$ & & & \\
\hline RBS & Mean \pm SD & $154.80 \pm 54.36$ & $137.73 \pm 25.90$ & $131.67 \pm 58.20$ & 4.711 & 0.016 & $\mathrm{~S}$ \\
\hline & Range & $80-250$ & $83-184$ & $74-190$ & & & \\
\hline
\end{tabular}

P-value >0.05: Non significant (NS); P-value <0.05: Significant (S); P-value< 0.01:

highly significant (HS), $\bullet$ : Repeated measure ANOVA test; $\$$ : Friedman test 
Table (4): Follow up of right optic nerve sheath diameter before and after mannitol among studied patients with increased ICP along 3 successive days

\begin{tabular}{|c|c|c|c|c|c|c|c|}
\hline \multirow{2}{*}{\multicolumn{2}{|c|}{ ONSD in millimeter }} & First day & Second day & Third day & \multirow[t]{2}{*}{ Test value• } & \multirow[t]{2}{*}{ P-value } & \multirow[t]{2}{*}{ Sig. } \\
\hline & & No. $=\mathbf{3 0}$ & No. $=30$ & No. $=30$ & & & \\
\hline \multicolumn{8}{|c|}{ Right 1} \\
\hline \multirow{2}{*}{ Before } & Mean \pm SD & $6.51 \pm 0.45$ & $5.45 \pm 0.51$ & $4.61 \pm 0.78$ & \multirow{2}{*}{207.694} & \multirow{2}{*}{0.000} & \multirow[t]{2}{*}{ HS } \\
\hline & Range & $5.6-7.2$ & $4.7-6.4$ & $3.7-6.8$ & & & \\
\hline \multirow[t]{2}{*}{ After } & Mean \pm SD & $5.81 \pm 0.51$ & $4.91 \pm 0.63$ & $4.23 \pm 0.64$ & \multirow[t]{2}{*}{198.094} & \multirow[t]{2}{*}{0.000} & \multirow[t]{2}{*}{ HS } \\
\hline & Range & $4.9-6.7$ & $3.9-6$ & $3.5-6$ & & & \\
\hline \multicolumn{8}{|c|}{ Right 2} \\
\hline \multirow[t]{2}{*}{ Before } & Mean \pm SD & $6.07 \pm 0.41$ & $5.07 \pm 0.53$ & $4.43 \pm 0.70$ & \multirow[t]{2}{*}{200.330} & \multirow[t]{2}{*}{0.000} & \multirow[t]{2}{*}{ HS } \\
\hline & Range & $5.2-6.8$ & $4.2-5.8$ & $3.7-6.4$ & & & \\
\hline \multirow[t]{2}{*}{ After } & Mean \pm SD & $5.49 \pm 0.47$ & $4.67 \pm 0.60$ & $4.02 \pm 0.56$ & \multirow[t]{2}{*}{299.314} & \multirow[t]{2}{*}{0.000} & \multirow[t]{2}{*}{ HS } \\
\hline & Range & $4.3-6.1$ & $3.7-5.6$ & $3.3-5.4$ & & & \\
\hline \multicolumn{8}{|c|}{ Right 3} \\
\hline \multirow[t]{2}{*}{ Before } & Mean \pm SD & $5.79 \pm 0.39$ & $4.79 \pm 0.56$ & $4.07 \pm 0.60$ & \multirow[t]{2}{*}{246.133} & \multirow[t]{2}{*}{0.000} & \multirow[t]{2}{*}{ HS } \\
\hline & Range & $5.1-6.4$ & $4-5.5$ & $3.4-5.7$ & & & \\
\hline \multirow[t]{2}{*}{ After } & Mean \pm SD & $5.19 \pm 0.48$ & $4.40 \pm 0.55$ & $3.85 \pm 0.50$ & \multirow[t]{2}{*}{226.008} & \multirow[t]{2}{*}{0.000} & \multirow[t]{2}{*}{$\mathrm{HS}$} \\
\hline & Range & $4.1-6$ & $3.4-5.2$ & $3.3-5.1$ & & & \\
\hline
\end{tabular}

P-value >0.05: Non significant (NS); P-value <0.05: Significant (S); P-value< 0.01: highly significant (HS), $\bullet$ : Repeated measure ANOVA test

Table (5): Follow up of left optic nerve sheath diameter before and after mannitol among studied patients with increased ICP along 3 successive days

\begin{tabular}{|c|c|c|c|c|c|c|c|}
\hline \multirow{2}{*}{\multicolumn{2}{|c|}{ ONSD in millimeter }} & First day & Second day & Third day & \multirow[t]{2}{*}{ Test value• } & \multirow[t]{2}{*}{ P-value } & \multirow[t]{2}{*}{ Sig. } \\
\hline & & No. $=30$ & No. $=30$ & No. $=30$ & & & \\
\hline \multicolumn{2}{|c|}{ Left 1} & & & & & & \\
\hline \multirow[t]{2}{*}{ Before } & Mean \pm SD & $6.75 \pm 0.45$ & $5.67 \pm 0.55$ & $4.82 \pm 0.66$ & \multirow{2}{*}{243.487} & \multirow{2}{*}{0.000} & \multirow[t]{2}{*}{ HS } \\
\hline & Range & $5.8-7.4$ & $4.6-6.8$ & $4-6.2$ & & & \\
\hline \multirow[t]{2}{*}{ After } & Mean \pm SD & $6.00 \pm 0.45$ & $5.05 \pm 0.53$ & $4.33 \pm 0.58$ & \multirow[t]{2}{*}{184.518} & \multirow[t]{2}{*}{0.000} & \multirow[t]{2}{*}{ HS } \\
\hline & Range & $5-7.1$ & $4.2-6$ & $3.6-5.6$ & & & \\
\hline \multicolumn{2}{|c|}{ Left 2} & & & & & & \\
\hline \multirow[t]{2}{*}{ Before } & Mean \pm SD & $6.34 \pm 0.51$ & $5.38 \pm 0.54$ & $4.51 \pm 0.62$ & \multirow{2}{*}{257.617} & \multirow[t]{2}{*}{0.000} & \multirow[t]{2}{*}{ HS } \\
\hline & Range & $5.6-7.3$ & $4.6-6.5$ & $3.8-6$ & & & \\
\hline \multirow[t]{2}{*}{ After } & Mean \pm SD & $5.72 \pm 0.44$ & $4.87 \pm 0.47$ & $4.09 \pm 0.53$ & \multirow[t]{2}{*}{272.622} & \multirow[t]{2}{*}{0.000} & \multirow[t]{2}{*}{ HS } \\
\hline & Range & $5-6.5$ & $4.3-6$ & $3.2-5.1$ & & & \\
\hline \multicolumn{2}{|c|}{ Left 3} & & & & & & \\
\hline \multirow[t]{2}{*}{ Before } & Mean \pm SD & $5.97 \pm 0.55$ & $5.06 \pm 0.58$ & $4.20 \pm 0.51$ & \multirow[t]{2}{*}{328.619} & \multirow[t]{2}{*}{0.000} & \multirow[t]{2}{*}{ HS } \\
\hline & Range & $5-7.1$ & $4.3-6.2$ & $3.6-5.2$ & & & \\
\hline \multirow[t]{2}{*}{ After } & Mean \pm SD & $5.39 \pm 0.48$ & $4.57 \pm 0.47$ & $3.89 \pm 0.41$ & \multirow[t]{2}{*}{334.026} & \multirow[t]{2}{*}{0.000} & \multirow[t]{2}{*}{ HS } \\
\hline & Range & $4.5-6.2$ & $4-5.8$ & $3.5-4.8$ & & & \\
\hline
\end{tabular}

P-value >0.05: Non significant (NS); P-value <0.05: Significant (S); P-value< 0.01: highly significant (HS), $\bullet$ Repeated measure ANOVA test

Table (6): Follow up of brain edema among studied patients with increased ICP along 3 successive days

\begin{tabular}{|c|c|c|c|c|c|c|c|c|c|}
\hline \multirow{2}{*}{$\begin{array}{c}\text { CT brain } \\
\text { edema }\end{array}$} & \multicolumn{2}{|c|}{ Day 1 } & \multicolumn{2}{|c|}{ Day 2} & \multicolumn{2}{|c|}{ Day 3} & Test & P-value & Sig. \\
\cline { 2 - 7 } value $^{*}$ & No. & $\%$ & No. & $\%$ & No. & $\%$ & & \\
\hline Negative & 0 & $0.0 \%$ & 0 & $0.0 \%$ & 23 & $76.7 \%$ & 61.791 & 0.000 & HS \\
\hline Positive & 30 & $100.0 \%$ & 30 & $100.0 \%$ & 7 & $23.3 \%$ & & & \\
\hline
\end{tabular}

P-value >0.05: Non significant (NS); P-value <0.05: Significant (S); P-value< 0.01:

highly significant (HS), *: Chi-square test 
Table (7): Relation between CT brain edema and right ONSD in third day before and after last dose

\begin{tabular}{|c|c|c|c|c|c|c|}
\hline \multicolumn{2}{c}{$\begin{array}{c}\text { ONSD } \\
\text { (Third day) }\end{array}$} & Negative CT brain & Positive CT brain & Test & P-value & Sig. \\
\cline { 2 - 4 } value & No. $=23$ & No. $=7$ & & \\
\hline \multirow{2}{*}{ Before } & Mean \pm SD & $3.83 \pm 0.31$ & $4.87 \pm 0.63$ & -6.027 & 0.000 & HS \\
\cline { 2 - 4 } & Range & $3.4-4.4 \mathrm{~mm}$ & $4.1-5.7 \mathrm{~mm}$ & & & \\
\hline \multirow{2}{*}{ After } & Mean \pm SD & $3.64 \pm 0.25$ & $4.56 \pm 0.50$ & -6.687 & 0.000 & HS \\
\cline { 2 - 4 } & Range & $3.3-4.2 \mathrm{~mm}$ & $3.7-5.1 \mathrm{~mm}$ & & & \\
\hline
\end{tabular}

P-value >0.05: Non significant (NS); P-value <0.05: Significant (S); P-value< 0.01: highly significant (HS), $\bullet$ : Independent t-test

Table (8): Relation between CT brain edema and left ONSD in third day before and after last dose

\begin{tabular}{|c|c|c|c|c|c|c|}
\hline \multicolumn{2}{c|}{$\begin{array}{c}\text { ONSD } \\
\text { (Third day) }\end{array}$} & Negative CT brain & Positive CT brain & Test & P-value & Sig. \\
\cline { 2 - 4 } & value• & & & \\
\hline \multirow{2}{*}{ Before } & Mean \pm SD & $3.98 \pm 0.34$ & No. $=7$ & -6.659 & 0.000 & HS \\
\cline { 2 - 4 } & Range & $3.6-5 \mathrm{~mm}$ & $4.6-5.2 \mathrm{~mm}$ & & & \\
\hline \multirow{2}{*}{ After } & Mean \pm SD & $3.75 \pm 0.31$ & $4.34 \pm 0.39$ & -4.173 & 0.000 & HS \\
\cline { 2 - 4 } & Range & $3.5-4.6 \mathrm{~mm}$ & $3.9-4.8 \mathrm{~mm}$ & & & \\
\hline
\end{tabular}

P-value >0.05: Non significant (NS); P-value <0.05: Significant (S); P-value< 0.01: highly significant (HS), $\bullet$ : Independent t-test
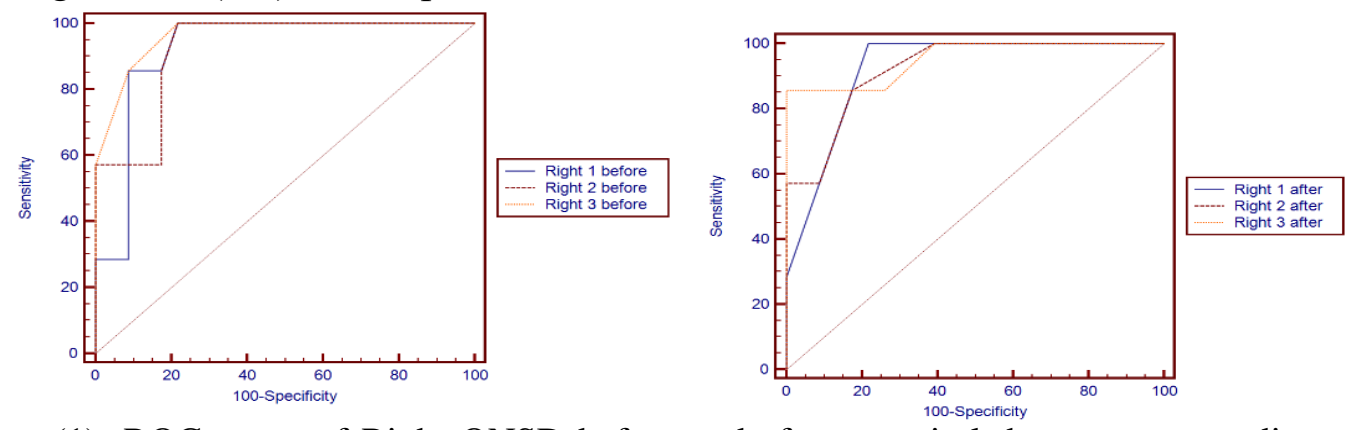

Diagram (1): ROC curve of Right ONSD before and after mannitol therapy as a predictor of brain edema

Table (9): ROC curve of Right ONSD before and after mannitol therapy as a predictor of brain edema

\begin{tabular}{|c|c|c|c|c|c|c|}
\hline Parameter & AUC & Cut of Point & Sensitivity & Specificity & PPV & NPV \\
\hline \multicolumn{7}{|l|}{ Before } \\
\hline Right 1 & 0.922 & $>4.6$ & 100.0 & 78.26 & 58.3 & 100.0 \\
\hline Right 2 & 0.922 & $>4.4$ & 100.0 & 78.26 & 58.3 & 100.0 \\
\hline Right 3 & 0.922 & $>4.0$ & 100.0 & 78.26 & 58.3 & 100.0 \\
\hline \multicolumn{7}{|l|}{ After } \\
\hline Right 1 & 0.922 & $>4.1$ & 100.0 & 78.26 & 58.3 & 100.0 \\
\hline Right 2 & 0.922 & $>4.0$ & 85.71 & 82.61 & 60.0 & 95.0 \\
\hline Right 3 & 0.953 & $>4.2$ & 85.71 & 100.0 & 100.0 & 95.8 \\
\hline
\end{tabular}

The previous ROC curve show the best cut off point in the right ONSD to predict brain edema before mannitol therapy is $>4.6$ mm with sensitivity of $100 \%$, specificity of $78.26 \%$, area under curve (AUC) 92.2\%, the positive predictive value (PPV) $58.3 \%$ and negative predictive value (NPV) $100 \%$. While the best cut off point after mannitol therapy is $>4.2 \mathrm{~mm}$ with sensitivity of 85.7 $\%$, specificity of $100 \%$ and AUC $95.3 \%$, the positive predictive value $100 \%$ and negative predictive value $95.8 \%$. 

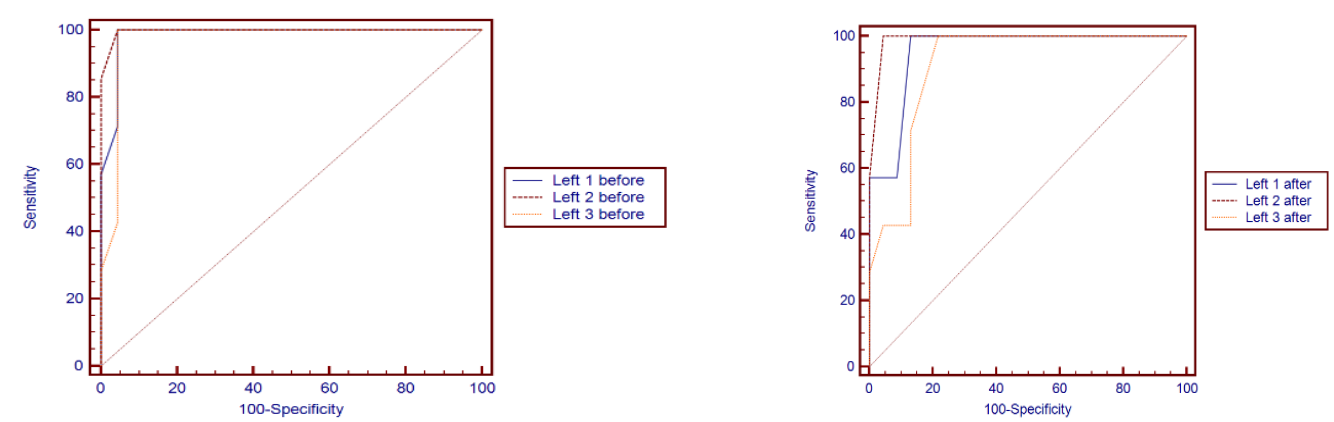

Diagram (2): ROC curve of left ONSD before and after mannitol therapy as a predictor of brain edema

Table (10): ROC curve of left ONSD before and after mannitol therapy as a predictor of brain edema

\begin{tabular}{|c|c|c|c|c|c|c|}
\hline Parameter & AUC & Cut of Point & Sensitivity & Specificity & PPV & NPV \\
\hline Before & \multicolumn{7}{|l|}{} \\
\hline Left 1 & 0.984 & $>5$ & 100.0 & 95.65 & 87.5 & 100.0 \\
\hline Left 2 & 0.997 & $>4.6$ & 100.0 & 95.65 & 87.5 & 100.0 \\
\hline Left 3 & 0.972 & $>4.5$ & 100.0 & 95.65 & 87.5 & 100.0 \\
\hline After & $>4.4$ & 100.0 & 86.96 & 70.0 & 100.0 \\
\hline Left 1 & 0.953 & $>4.3$ & 100.0 & 95.65 & 87.5 & 100.0 \\
\hline Left 2 & 0.991 & $>3.8$ & 100.0 & 78.26 & 58.3 & 100.0 \\
\hline Left 3 & 0.910 &
\end{tabular}

The previous ROC curve show the best cut off point in the left ONSD to predict brain edema before mannitol therapy is $>4.6 \mathrm{~mm}$ with sensitivity of $100 \%$, specificity of 95.65 $\%$, area under curve (AUC) $99.7 \%$, the positive predictive value $87.5 \%$ and negative predictive value $100 \%$. While the best cut off point after mannitol therapy is $>4.3 \mathrm{~mm}$ with sensitivity of $100 \%$, specificity of $95.65 \%$ and AUC $99.1 \%$, the positive predictive value $87.5 \%$ and negative predictive value $100 \%$.

\section{DISCUSSION:}

Intracranial pressure (ICP) is a major predictor of neurological deterioration in patients with TBI and post-traumatic intracranial hypertension (ICH) is being associated with poor neurological outcome. Prompt identification of elevated intracranial pressure is lifesaving and invasive monitoring is not always utilized appropriately $^{(7)}$.

Normal ICP in healthy adults is usually regarded as $5-15 \mathrm{mmHg}$ and in TBI an Intracranial pressure (ICP) of $>20 \mathrm{mmHg}$ is widely accepted as intracranial hypertension $(\mathrm{ICH})^{(8)}$.

Measurement of ONSD is rapidly gaining popularity as it is quick, easily available and has a short learning curve. The optic nerve sheath is continuous with dura mater, and subarachnoid compartment of optic nerve communicates with that of brain so that any increase in ICP causes expansion of $\mathrm{ONSD}^{(9)}$.

Osmotherapy is one treatment intervention in the care of patients with severe head injury resulting in cerebral edema and intracranial hypertension. The effect of hyperosmolar solutions on brain tissue was first studied nearly 90 years ago. Since that time, mannitol has become the most widely used hyperosmolar solution to treat elevated intracranial pressure ${ }^{(6)}$.

We aimed in our study to evaluate the efficacy of dehydrating therapy in reduction of increased intracranial pressure in traumatic brain injuries with ultrasonography measurement of optic nerve 
sheath diameter (ONSD) compared with CT brain.

In emergency room, after first aid, primary and secondary survey including CT brain (to detect brain injuries and signs of increasing ICP) was done, all patients were examined by ultrasound to monitor ONSD in both eyes separately; we used a cut off value for ONSD > $5.0 \mathrm{~mm}$ to diagnose increase in ICP > $20 \mathrm{~mm} \mathrm{Hg}$.

In ICU unit, we perform ocular ultrasound in axial technique in both eyes 30 minute before and 60 minute after Mannitol 20\% administration in a dose of $0.5-2 \mathrm{gm} / \mathrm{kg}$ every 8 hours intravenously over a period of 30 minutes for 72 hours. CT brain was done again after 24 hour of admission to follow brain injuries, and repeated after 72 hour to evaluate the efficacy of osmotherapy.

This study is a prospective observational study conducted on 30 traumatic brain injury patients after road traffic accident, there were 5 females and 25 males their age range from $(18-52)$ with mean \pm SD $(34.70$ \pm 10.07), initial GCS range $(4-12)$ with mean $\pm \mathrm{SD}(9.23 \pm 2.88)$.

In follow up of vital data we found there was no statistically significant difference in $\mathrm{BP}, \mathrm{HR}$ and temperature.

This result agree with systematic review and meta-analysis done Tsaousi et al $^{(10)}$ to show cardiac output changes after osmotic therapy in neurosurgical and neurocritical care patients, and concluded that mannitol induced a consistent MAP deterioration, which became apparent immediately after the end of the infusion and lasted up to 45 min, and reported this effect was not of statistical importance and also in HR.

But this study disagree with our study in significance of CVP, we found there was highly statistically significant increase in CVP, we suggest that due to fluid resuscitation in trauma patients.
In present study we found there was highly statistically significant increase in GCS after mannitol therapy, and this disagree with study of Salehpour et al $^{(11)}$ that evaluate the effect of three different mannitol $20 \%$ doses on cerebral edema and consciousness levels in traumatic brain injury and concluded that GCS was slowly increased during the treatment in all groups. and GCS increase after $48 \mathrm{~h}$ of admission in all groups was not significantly different $(\mathrm{P}=0.08)$.

In our study there was highly statistically significant increase in serum potassium with minimal decrease in serum sodium but not statistically significant and this result agree with Czupryna et al. ${ }^{(12)}$ that show the effect of a single dose of mannitol on hydration status and electrolyte concentrations in patients with tick-borne encephalitis.

Also in our study there was no statistically significant difference in urea and statistically significant decrease in serum creatinine, this results agree with Sari et al. ${ }^{(13)}$ that monitored the effect of mannitol on serum creatinine and BUN and concluded that no significant change.

The results of our study show that ONSD is highly significant in early detection on increasing ICP.

In right eye there increase in ONSD in all patients range $(5.6-7.2(\mathrm{~mm}$ (SD $6.51 \pm 0.45)$ $\mathrm{P}$ value $<0.001$, the best cut off point in the right ONSD to predict brain edema before mannitol therapy is $>4.6 \mathrm{~mm}$ with sensitivity of $100 \%$, specificity of $78.26 \%$, area under curve (AUC) $92.2 \%$.

In left eye there increase in ONSD range $(5.8-7.4) \mathrm{mm}$. (SD $6.75 \pm 0.45) \mathrm{P}$ value $<$ 0.00 ', the best cut off point in the left ONSD to predict brain edema before mannitol therapy is $>4.6 \mathrm{~mm}$ with sensitivity of $100 \%$, specificity of $95.65 \%$, area under curve (AUC) $99.7 \%$. 
This result agree with Tayal et $\boldsymbol{a l}^{(4)}$ by using a described ONSD cut-off of $5 \mathrm{~mm}$, he performed a prospective blinded observational study in the emergency department on 59 adult patients with a mean age of 38 years, suspected of having raised ICP. The mean ONSD in patients with CT evidence of raised ICP was $6.37 \mathrm{~mm}$, and in the group without evidence of raised ICP, the mean ONSD was $4.94 \mathrm{~mm}$. Using $5 \mathrm{~mm}$ as a cut-off point, the study described a sensitivity of $100 \%$, and specificity of $63 \%$ for predicting raised ICP.

In addition, Amini et al. ${ }^{(14)}$ also used the sonographic measurement of the ONSD and located that the ONSD of greater than 5.5 $\mathrm{mm}$ was a good indicator of high ICP $(>20$ $\mathrm{cm} \mathrm{H} 2 \mathrm{O}$ ) with sensitivity and specificity of $100 \%$ (95\% CI, 100-100) $(\mathrm{P}<0.001)$.

Rajajee et $\boldsymbol{a l}^{(15)}$ who performed a prospective blinded observational study on 65 patients in the ICU. All patients in the study had either had an EVD or intra-parenchymal ICP monitor in situ. The authors used individual as well as mean ONSD values to account for possible fluctuation in the ICP during ONSD measurement. For the individual ONSD measurements the median was $0.53 \mathrm{~cm}$ for ICP $>20 \mathrm{mmHg}$, and was 0.4 $\mathrm{cm}$ for ICP $<20 \mathrm{mmHg}$ ( $\mathrm{p}<0.0001)$. An ONSD of $0.48 \mathrm{~cm}$ demonstrated a sensitivity of $96 \%$ and specificity of $94 \%$ for predicting ICP $>20 \mathrm{mmHg}$.

Jeon et $\boldsymbol{a l}^{(16)}$ concluded that ONSD linear correlated with directly measured ICP in patients with brain lesions. The mean values of ONSD in patients with increased ICP was $5.80 \pm 0.45 \mathrm{~mm}$, which was significantly higher than that in those without increased ICP $(5.30 \pm 0.61 \mathrm{~mm})$ $(\mathrm{P}<0.01)$ and the optimal cut-off point of ONSD for identifying increased ICP was 5.6 $\mathrm{mm}$, yielding a sensitivity of $93.75 \%$ and a specificity of $86.67 \%$. That differ from our study that we depend on noninvasive method to detect ICP not directly in spite of it more accurate.
In correlation between ONSD and CT brain, we found it highly significant in present study and that agree with Kim et al. ${ }^{(17)}$ which performed a comparison of ultrasonography and computed tomography for measuring optic nerve sheath diameter for the detection of elevated intracranial pressure and concluded that the median USG-ONSD and CT-ONSD were significantly higher in patients with elevated intracranial pressure than in patients with normal intracranial pressure. The interclass correlation coefficient between USG-ONSD and CT-ONSD was 0.785 (95\% CI 0.715-0.837). A Bland-Altman plot showed significant agreement between USG and CT measurements. The optimal cutoff for detecting elevated intracranial pressure was $>5.3 \mathrm{~mm}$ (sensitivity of $75.4 \%$ and specificity of $90.8 \%$ ) for USG and $>5.0 \mathrm{~mm}$ (sensitivity of $68.4 \%$ and specificity of $85.2 \%$ ) for CT.

Also study by Wang et $\boldsymbol{a l l}^{(18)}$ which included 60 patients who underwent measurement of ONSD prior to lumbar puncture on admission and during follow up, concluded that ICP was strongly correlated with $\operatorname{ONSD}(\mathrm{r}=0.758, \mathrm{p}<0.001)$ and this association was independent of all other factors like age, sex, BMI, mean arterial pressure and diastolic blood pressure. It also states that ultrasonographic ONSD measurements provide a potential noninvasive method to quantify ICP that can be conducted at the bedside.

Another study performed in the Indian population by Shirodkar et al. ${ }^{(19)}$ evaluated the efficacy of ONSD by ultrasonography as a non-invasive method for detecting raised intracranial pressure in intensive care unit to compare with CT/MRI findings of raised ICP and to prognosticate ONSD value with treatment. The results showed a sensitivity of detecting raised ICP by ONSD to be $84.6 \%$ and a specificity approaching around $99 \%$.

The use of ONSD measurement specifically in the acute phase (within 6 hours) to detect intracranial haemorrhage 
(ICH), was investigated by Skoloudik et $\boldsymbol{a l}^{(20)}$. This study included 31 patients with ICH, comparing them to 31 control patients. Sonographic ONSD measurements were performed at 3 and $12 \mathrm{~mm}$ behind the globe. Relative ONSD enlargement of $>0.66 \mathrm{~mm}$ (> $21 \%$ ) demonstrated an accuracy of $90.3 \%$ for predicting an ICH volume $>2.5 \mathrm{~cm} 3$. The authors then used an ONSD value of $>5 \mathrm{~mm}$, demonstrating a sensitivity of $0.708(95 \% \mathrm{CI}$ $0.620-0.708)$, specificity of $1.000(0.697-$ $1.000)$, positive predictive value of 1.000 (95\% CI $0.875-1.000)$ and a negative predictive value of $0.500(0.348-0.652)$, concluding that enlargement of the ONSD may be detectable in the hyperacute stage of increased ICP. The use of ONSD to evaluate the clinical evolution of $\mathrm{ICH}$ beyond the acute stage was also later confirmed.

Results of our study show highly significant decrease in ONSD after osmotherapy with mannitol $20 \%$ that indicate successful treatment correlate with negative CT finding of increasing ICP in third day.

In right eye there decrease in ONSD in third day range $(3.3-5.1) \mathrm{mm}$ (SD $3.85 \pm$ $0.50) \mathrm{P}$ value $<0.001$. In left eye there decrease in ONSD range $(3.5-4.8) \mathrm{mm}(\mathrm{SD} 3.89 \pm$ $0.41) \mathrm{P}$ value $<0.001$.

This results agree with Launey et al. ${ }^{(21)}$ who performed a study to determine the rate of ONSD variation after Mannitol administration for increased ICP episodes. They included thirteen patients in their study comparing and correlating the changes in ONSD, pulsatility index and invasively monitored ICP. The ONSD significantly decreased after Mannitol infusion from 6.3 to $5.56 \mathrm{~mm}(\mathrm{p}=0.0007)$. Concomitantly the intracranial pressure also decreased for $35(32-41)$ to $25(22-29) \mathrm{mmHg}(\mathrm{p}=0.001)$ and the CPP increased from 47 to 69 $(p=0.003)$. The study concluded that the variations of ONSD appear to be an interesting and effective parameter to evaluate the efficacy of osmotherapy for elevated ICP episodes in patients with acute brain injury/SAH.

A study by Jun et al. ${ }^{(22)}$ aimed at studying the effect of mannitol on ONSD as a surrogate for intracranial pressure during robot assisted laparoscopic prostatectomy with pneumo-peritoneum and the tredelenburg position. Mannitol $(0.5 \mathrm{~g} / \mathrm{kg})$ was administered after pneumoperitoneum establishment and shifting to the Trendelenburg position. ONSDs were measured at six predetermined time points: 10 minutes after anesthesia induction (T0); 5 minutes after pneumoperitoneum and the Trendelenburg position before Mannitol administration (T1); 30 minutes (T2), 60 minutes (T3), and 90 minutes (T4) after completion of Mannitol administration during pneumoperitoneum and the Trendelenburg position; and at skin closure in the supine position (T5). Results showed that ONSDs were significantly lower at T2, $\mathrm{T} 3$, and T4 than at T1 (all p $<0.001$ ), with the greatest decrease observed at $\mathrm{T} 4$ compared with $\mathrm{T} 1(4.46 \pm 0.2 \mathrm{~mm}$ vs $4.81 \pm$ $0.3 \mathrm{~mm}, \mathrm{p}<0.001)$ while mean arterial blood pressure and heart rate were also significantly different. However regional cerebral oxygen saturation, cardiac output, corrected flow time, peak velocity, body temperature, arterial $\mathrm{CO} 2$ partial pressure, peak airway pressure, plateau airway pressure, dynamic compliance, and static compliance were not significantly different during pneumoperitoneum and the Trendelenburg position.

A study by Nash et al. ${ }^{(23)}$ uses ONSD to diagnose raised ICP along with correlation with CT findings. It also reviews the literature from the past and concludes that $<0.50 \mathrm{~cm}$ ONSD ensured normal pressure (95\% CI 0.469-0.540, p<0.001). The study also quantifies the inter-observer variability in ONSD measurement $(0.001-0.002 \mathrm{~cm})$. 


\section{Conclusion:}

The results of this study indicate the acceptable accuracy of ultrasound of the optic nerve in comparison with CT scan as the gold standard for ONSD.

CT scan could be replaced by ultrasonography as an accessible, easy, noninvasive method, with appropriate sensitivity and specificity, as well as a screening method for early ICP detection whenever invasive ICP evaluation is contraindicated and/or is not available and in unstable patients, among the patients with traumatic head injuries.

Also ONSD could be used as a tool to evaluate the efficacy and successful treatment by dehydrating measures in cases of increased ICP and can be utilized as a tool for decision making and point-of-care utility.

\section{REFERENCES:}

1. Wang, J., Ren, Y., Wang, S. F., Kan, L. D., Zhou, L. J., Fang, H. M., \& Fan, H. (2021): Comparative efficacy and safety of glycerol versus mannitol in patients with cerebral oedema and elevated intracranial pressure: A systematic review and meta-analysis. Journal of Clinical Pharmacy and Therapeutics, 46(2): 504-514.

2. Raboel, P. H., Bartek, J., Andresen, M., Bellander, B. M., \& Romner, B. (2012): Intracranial pressure monitoring: invasive versus non-invasive methods - a review. Critical care research and practice, 2012.

3. Kimberly, H. H., \& Noble, V. E. (2008): Using MRI of the optic nerve sheath to detect elevated intracranial pressure. Critical care, 12(5): 1-2.

4. Tayal, V. S., Neulander, M., Norton, H. J., Foster, T., Saunders, T., \& Blaivas, M. (2007): Emergency department sonographic measurement of optic nerve sheath diameter to detect findings of increased intracranial pressure in adult head injury patients. Annals of emergency medicine, 49(4): 508514.
5. Sekhon, M. S., Griesdale, D. E., Robba, C., McGlashan, N., Needham, E., Walland, K., \& Menon, D. K. (2014): Optic nerve sheath diameter on computed tomography is correlated with simultaneously measured intracranial pressure in patients with severe traumatic brain injury. Intensive care medicine, 40(9): 1267-1274.

6. Knapp, J. M. (2005): Hyperosmolar therapy in the treatment of severe head injury in children: mannitol and hypertonic saline. AACN Advanced Critical Care, 16(2): 199211.

7. Dunn, L. T. (2002): Raised intracranial pressure. Journal of Neurology, Neurosurgery \& Psychiatry, 73(suppl 1): i23-i27.

8. Bratton, S. L., Chestnut, R. M., Ghajar, J., McConnell Hammond, F. F., Harris, O. A., Hartl, R., \& Wright, D. W. (2007): Brain Trauma Foundation; American Association of Neurological Surgeons; Congress of Neurological Surgeons; Joint Section on Neurotrauma and Critical Care, AANS/CNS. Guidelines for the management of severe traumatic brain injury. J Neurotrauma, 24(Suppl 1): S59S64.

9. Shrestha, G. S. (2015): Point-of-care ultrasonography in critically ill patients. Kathmandu University Medical Journal, 13(1): 83-87.

10. Tsaousi, G., Stazi, E., Cinicola, M., \& Bilotta, F. (2018): Cardiac output changes after osmotic therapy in neurosurgical and neurocritical care patients: a systematic review of the clinical literature. British journal of clinical pharmacology, 84(4): 636-648.

11. Salehpour, F., Asghari, M., Shimia, M., Ebrahimi, H., Mohammad Khanli, H., Mohammad Bazzazi, A., \& Ghojazadeh, M. (2013): Effect of three different mannitol $20 \%$ doses on cerebral edema and consciousness levels in traumatic brain injury. Life Science Journal, 10(SUPPL. 7): 1228-1231. 
12. Czupryna, P., Moniuszko-Malinowska, A., Grygorczuk, S., Pancewicz, S., Dunaj, J., Król, M., \& Zajkowska, J. (2018): Effect of a single dose of mannitol on hydration status and electrolyte concentrations in patients with tick-borne encephalitis. Journal of International Medical Research, 46(12): 5083-5089.

13. Sari, E. A., Suharjono, S., \& Wahyuhadi, J. (2020): Monitoring Serum Creatinine, Blood Urea Nitrogen in Patients Brain Injury with Mannitol Therapy. Folia Medica Indonesiana, 56(4): 254-260.

14. Amini, A., Kariman, H., Dolatabadi, A. A., Hatamabadi, H. R., Derakhshanfar, H., Mansouri, B., \& Eqtesadi, R. (2013): Use of the sonographic diameter of optic nerve sheath to estimate intracranial pressure. The American journal of emergency medicine, 31(1): 236-239.

15. Rajajee, V., Vanaman, M., Fletcher, J. J., \& Jacobs, T. L. (2011): Optic nerve ultrasound for the detection of raised intracranial pressure. Neurocritical care, 15(3): 506515.

16. Jeon, J. P., Lee, S. U., Kim, S. E., Kang, S. H., Yang, J. S., Choi, H. J., \& Kim, Y. S. (2017): Correlation of optic nerve sheath diameter with directly measured intracranial pressure in Korean adults using bedside ultrasonography. PLoS One, 12(9): e0183170.

17. Kim, D. Y., Kim, S. Y., Hong, D. Y., Sung, B. Y., Lee, S., Paik, J. H., \& Jung, H. M. (2021): Comparison of ultrasonography and computed tomography for measuring optic nerve sheath diameter for the detection of elevated intracranial pressure. Clinical Neurology and Neurosurgery, 204, 106609.

18. Wang, L. J., Chen, L. M., Chen, Y., Bao, L. Y., Zheng, N. N., Wang, Y. Z., \& Xing, Y. Q. (2018): Ultrasonography assessments of optic nerve sheath diameter as a noninvasive and dynamic method of detecting changes in intracranial pressure. JAMA ophthalmology, 136(3): 250-256.
19. Shirodkar, C. G., Rao, S. M., Mutkule, D. P., Harde, Y. R., Venkategowda, P. M., \& Mahesh, M. U. (2014): Optic nerve sheath diameter as a marker for evaluation and prognostication of intracranial pressure in Indian patients: An observational study. Indian journal of critical care medicine: peer-reviewed, official publication of Indian Society of Critical Care Medicine, 18(11): 728.

20. Školoudík, D., Herzig, R., Fadrná, T., Bar, M., Hradílek, P., Roubec, M., \& Kan̆ovský, P. (2011): Distal enlargement of the optic nerve sheath in the hyperacute stage of intracerebral haemorrhage. British journal of ophthalmology, 95(2): 217-221.

21. Launey, Y., Nesseler, N., Le Maguet, P., Mallédant, Y., \& Seguin, P. (2014): Effect of osmotherapy on optic nerve sheath diameter in patients with increased intracranial pressure. Journal of neurotrauma, 31(10): 984-988.

22. Jun, I. J., Kim, M., Lee, J., Park, S. U., Hwang, J. H., Hong, J. H., \& Kim, Y. K. (2018): Effect of mannitol on Ultrasonographically measured optic nerve sheath diameter as a surrogate for intracranial pressure during robot-assisted laparoscopic prostatectomy with pneumoperitoneum and the Trendelenburg position. Journal of endourology, 32(7): 608-613.

23. Nash, J. E., O’Rourke, C., \& Moorman, M. L. (2016): Transocular ultrasound measurement of the optic nerve sheath diameter can identify elevated intracranial pressure in trauma patients. Trauma, 18(1): 28-34. 
الارتباط بين التقييم بالموجات فوق الصوتية لقطرغمد العصب البصري والأشعة المقطعية فى مراقبة

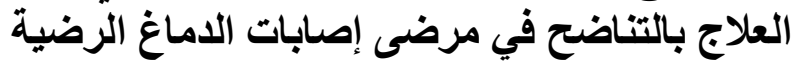

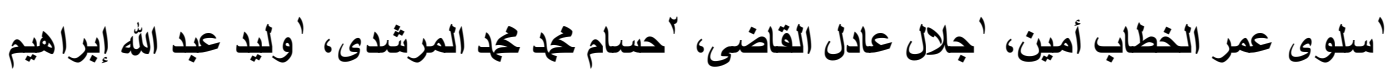

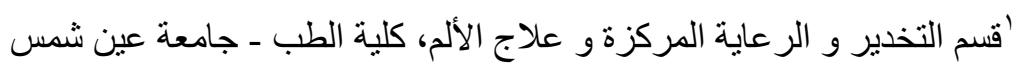

'طبيب مقيم رعاية مركزة، مستشفي بلييس المركزي

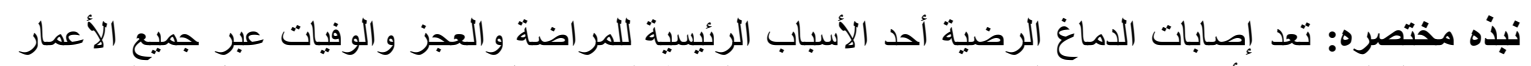

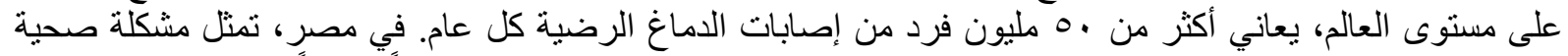

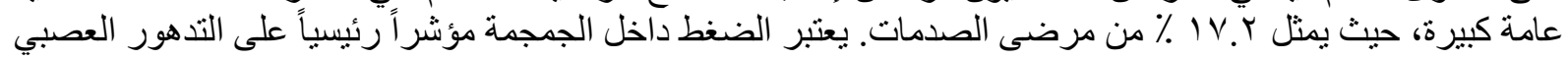

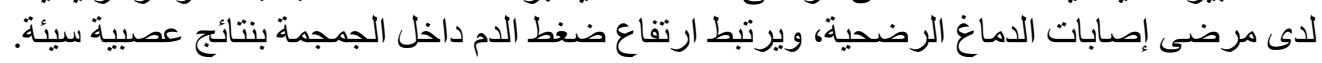

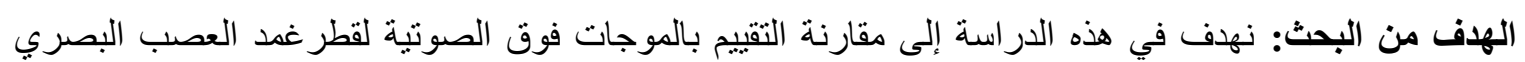

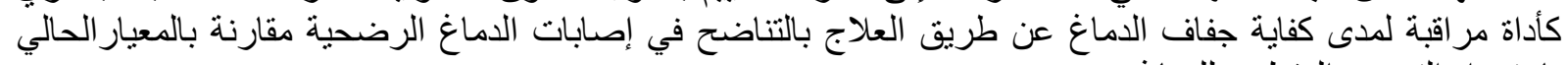
باستخدام التصوير المقطعي للأماغ. مغاف.

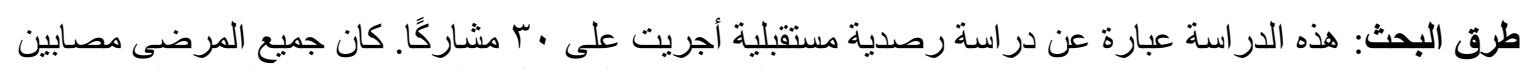

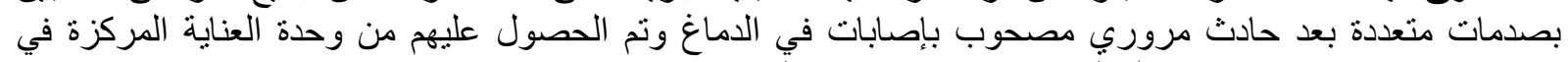

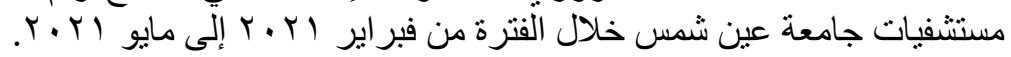

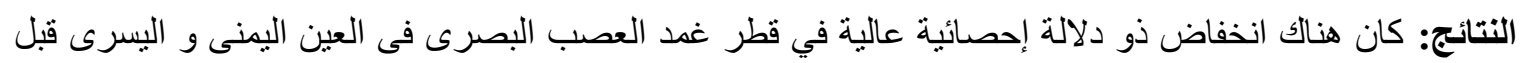
وبعد جر عة المانيتول من اليوم الاول إنى ذانى اليوم الثالث.

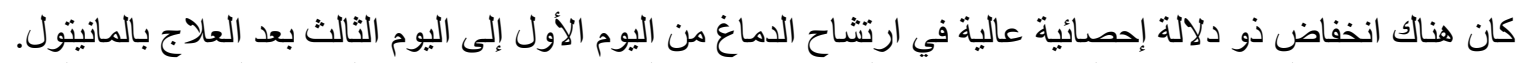

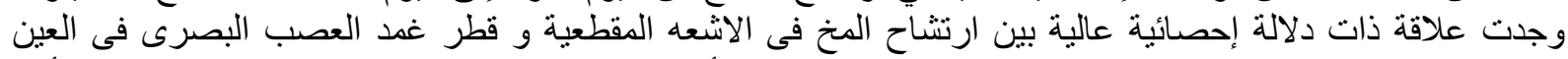
اليمنى و اليسرى قبل وبعد جر عة المانيتول فى اليوم الثالث ,حيث أن الن الاشعة الثقطعية تكون إيجابية بالفعل في اليوم الأول و الثناني.

الخلاصة: خلصنا إلى أنه يمكن استخدام قطر غمد العصب البصرى كأداة لتقييم الفعالية والعلاج الناجح من خلال

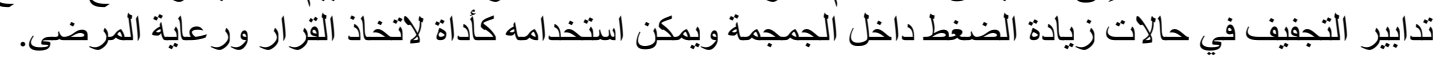

